\title{
LESSONS FROM THE LEADERS OF GREEN DESIGNED COMMERCIAL BUILDINGS \\ IN AUSTRALIA
}

\author{
SANDY BOND \\ Lincoln University, New Zealand
}

\section{ABSTRACT}

This research identifies property stakeholders' motivations for, and experiences of, achieving proven examples of best practice in sustainable development in Australia. The results can help inform others of how to design sustainable buildings that work well in both financial and non-financial terms. The results show that the most successful outcomes are achieved through the use of an integrated approach: allowing the design team to innovate solutions, and involving all parties early in the design process. Further, adopting tried and tested technologies, ensuring the tenant fit-out matches the base building, and that the building is finely tuned on a regular basis, is critical.

Keywords: Sustainability, energy efficiency, green star ratings, greenhouse gas emissions

\section{INTRODUCTION}

The aim of this paper is to study best practice examples of sustainable commercial building development to examine the learning that was gained from the process and to determine what can be done to improve the uptake of sustainable building practices that will improve the energy efficiency of buildings. Improving energy efficiency of buildings has been identified as the quickest and most cost effective way of reducing greenhouse gas emissions.

Buildings in Australia account for $23 \%$ of Australia's greenhouse gas emissions, consume $40 \%$ of Australia's total energy output and the cost to the economy of poor indoor environmental quality is estimated at $\$ 12 \mathrm{~b}$ annually (Green Building Council Australia, 2007). By comparison, US buildings account for 38\% of America's GHG emissions, while the figure for the UK is around $42 \%$.

The Green Building Council of Australia's more recent estimates suggest that commercial buildings currently contribute $8.8 \%$ to national greenhouse gas emissions. Electricity is responsible for the majority of emissions (89\%). In terms of the operational energy applications, cooling (28\%), air handling (22\%), lighting (21\%) 
and heating (13\%) account for $84 \%$ of commercial building greenhouse gas emissions. A commercial building sector baseline study found that office buildings and hospitals were the two largest emitters by building type, causing around $40 \%$ of total commercial building sector emissions (Green Building Council of Australia, 2008a).

\section{BACKGROUND}

In recognition of the significant environmental impacts associated with buildings, in 2003 the Department of Environment \& Heritage (DEH, renamed the Department of the Environment, Water, Heritage and the Arts), the Australian Building Codes Board (ABCB), and the CRC for Construction Innovation (CRC-CI) commissioned a scoping study "Sustainability and the Building Code of Australia" to investigate whether it was appropriate for sustainability requirements to be included in the Building Code of Australia (BCA). In June 2004, the Australian Building Code Board (ABCB) endorsed some of the key recommendations of the research and announced that sustainability should become a goal of the Building Code of Australia (alongside the existing BCA goals of health, safety and amenity).

In August 2004, the Ministerial Council on Energy agreed to a comprehensive set of measures comprising the first stage of the National Framework for Energy Efficiency (NFEE). The National Framework is a comprehensive package of measures covering the residential, commercial and industrial sectors, designed to overcome the barriers and challenges that prevent the market delivering the actual economic potential of energy efficiency.

At the Council of Australian Governments (COAG, 2009) meeting on April 30th 2009, the States and the Federal Government signed the National Strategy on Energy Efficiency 2009-2020 Memorandum of Understanding (MOU) and released a draft National Strategy on Energy Efficiency. ${ }^{1}$

Measures to drive growth in the number of highly energy efficient commercial buildings across Australia include:

1. Increasing the stringency of energy efficiency requirements for all classes of commercial buildings in the Building Code of Australia from 2010;

2. Phase in from 2010 the mandatory disclosure of energy efficiency in commercial buildings- phase 1 applying to large office buildings of $2000 \mathrm{~m}^{2}$ or larger and commercial buildings owned or leased by Commonwealth,

\footnotetext{
${ }^{1}$ The European Union is taking a much more ambitious approach under the EU Energy Performance of Buildings Directive, with the requirement for new buildings or existing buildings to be sold or let to have an Energy Performance Certificate by October 2008 (Dixon, et al., 2008).
} 
State or Territory Governments. Phase 2 may apply to other building types including hotels, retail, schools and hospitals;

3. Reforming current building energy efficiency standard and assessment processes to achieve consistency across the nation.

The strategy also recognises that governments are significant users of energy and proposes measures for government to "work in partnership and lead the way". Measures include improving the performance of buildings owned or occupied by governments by the promotion of energy performance contracting to upgrade buildings; developing a National Green Lease Policy, and placing greater emphasis on energy efficiency in procurement practices (De Wit and Webb, 2009).

\section{LITERATURE REVIEW}

To drive the adoption of green building practices through market-based solutions, a range of tools have been developed in Australia to measure the various aspects of the environmental performance of new and existing buildings against benchmarks. The three most prominent environmental rating systems for commercial properties in operation are: Green Building Council of Australia's (GBCA) Green Star; Australian Building Greenhouse Rating (ABGR); and the National Australian Built Environment Rating System (NABERS). According to Jones Lang LaSalle (2009), achieving green ratings (GreenStar and NABERS) increased in importance as a driver from $64 \%$ in 2006 to $74 \%$ in 2008.

\section{Leadership in sustainable buildings}

The government and other public-sector bodies are leading by example in their briefs for sustainable buildings. For example, South Australia, Victoria and Queensland state governments have set a minimum 5 Star Green Star standard for all government office accommodation. The Federal Government has a 4.5 Star NABERS rating minimum requirement for office areas over $2000 \mathrm{~m}^{2}$, with all new buildings to be 5 Star NABERS energy. Kats (2003) helps to explain this. He suggests that governments see the benefits of sustainable buildings more through social and environmental benefits with some regard to the financial, whereas the private sector is more driven by the financial returns, particularly when most of the benefits of sustainable development accrue to the tenants rather than the investor.

The large progressive corporations in the private sector are also a leading driver for green buildings. Investors are increasingly interested in corporate social responsibility and socially responsible investing, come to be called Responsible Property Investing. Responsible Property Investing (RPI) has been defined as maximizing the positive effects and minimizing the negative effects of property ownership, management and development on society and the natural environment in ways that are consistent with 
investor goals and fiduciary responsibilities (Pivo and McNamara 2005). According to Newell (2008), a number of listed property trusts (LPTs) are providing leadership in the implementation of sustainable commercial property practices. For example, Investa, Mirvac, Stockland, ING, DB RREEF and GPT are delivering excellence and international best practice figuring prominently in international sustainability indices such as the Dow Jones World Sustainability Index (DJWSI) and the Global Environmental Real Estate Index (GEREI). For example, in 2009, GPT was the DJWSI real estate super-sector leader, ${ }^{2}$ and ranked number 1 globally in the inaugural GEREI. Further, GPT was awarded the Banksia Foundation's Large Business Sustainability Award. ${ }^{3}$ In 2008, the three top companies in the Carbon Disclosure Project -Climate Leadership Index were from Australian Real Estate LPTs: Investa, GPT, Mirvac.

\section{The Economic Argument for Sustainable Practices}

According to Myers et al. (2008), for sustainability to gain industry-wide acceptance and uptake, the majority of building owners and investors need to be assured of depth in the market, as well as the financial certainty and viability of sustainable buildings. Economic return is a key driver in the property investment market. While there have been numerous surveys of industry stakeholders to determine the value of sustainability, there are very few quantitative studies. Some of these are outlined in the next section.

The only comprehensive studies known to date are coming from the US, where sales data are more readily available and sustainable ratings for buildings have been in existence longer (Leadership in Energy and Environmental Design (LEED) was developed in 1998 in the US,) than is the case for Australia, or NZ, (2003 and 2005 respectively). ${ }^{4}$

A study by Fuerst and McAllister (2009) of the effect of eco-labeling (LEED and Energy Star) on the occupancy rates of commercial offices in the US found a significant positive relationship between occupancy rate and the eco-label. Controlling for differences in age, height, building class, and quality, the results suggest that occupancy rates are approximately 8\% higher in LEED-labeled offices and 3\% higher in energy star labeled offices.

Miller et al. (2008), using the CoStar database, compared all USA-based Energy Star and LEED certified office buildings with a large sample of buildings without these ratings that were of similar size, location, class, tenancy and year-built to determine if

\footnotetext{
${ }^{2}$ http://www.sustainability-index.com/07_htmle/indexes/djsiworld_supersectorleaders_09.html [accessed 12 June 2010].

${ }^{3}$ http://cr.gpt.com.au/ [accessed 12 June 2010].

${ }^{4}$. BRE Environmental Assessment Method (BREEAM) was one of the earliest rating tools to measure the sustainability of new non-domestic buildings, developed in the UK in 1990.
} 
there is any rent or price premium for rated buildings. According to the study, LEED buildings command rent premiums of $\$ 11.33$ per square foot over their non-LEED peers and rental rates in Energy Star buildings represent a \$2.40 per square foot premium over comparable non-Energy Star buildings. Energy Star buildings are selling for an average of $5.76 \%$ more, while LEED buildings command a $9.94 \%$ premium.

However, the LEED certification was not broken down into the various levels of certified, silver, gold or platinum, so the results provide a preliminary indication only as to the value added by the general LEED rating. This aspect of the study was strongly criticized by Muldavin (2008), who had concerns too about the peer building selection approach used in the study. Muldavin further points out that the study does not directly link the costs and risks undertaken to achieve the stated rent or value premiums, which the title of the work implies.

A study by Eichholtz, Kok and Quigley (2008) provides more substantive evidence on the economic value of the certification of "green buildings" in the commercial sector. They analyzed data on 694 certified Energy-Star and LEED-rated office buildings and on 7489 other office buildings located within a quarter mile of the certified buildings. They found evidence that rents for green offices are about $2 \%$ higher than rents for comparable buildings located nearby. Effective rents, i.e., rents adjusted for the occupancy levels in office buildings, are about $6 \%$ higher in green buildings than in comparable office buildings nearby. The selling prices of green buildings, all things being equal, are about $16 \%$ higher than other nearby buildings that do not have these green credentials. When the certification is reported separately for the Energy Star and the LEED systems, there is no evidence that the latter is associated with higher selling prices, or higher rents. Further, the authors point out that it is not yet possible to distinguish between the effects on market value of energy savings and conservation from the other valuable attributes of a rating. Lastly, the authors note that the results are neighborhood specific.

\section{Improved productivity from green buildings}

According to a report by the Green Building Council of Australia (2008b), tenants have become less focused on savings in operating costs, and are placing a higher value on the intangible benefits such as productivity, staff attraction and retention, and reduced sick leave and absenteeism.

Miller et al. (2008) estimate the productivity benefits from environmentally sustainable building designs to be as much as 10 times the energy savings from green efforts. Such benefits include lower absenteeism, higher productivity, fewer headaches at work, etc. 
The problem has been that productivity and health benefits are much harder to assess and measure with any degree of accuracy than the more easily quantifiable energy and water savings from green buildings. However, there are a growing number of such studies that demonstrate the correlation between improvements in indoor air quality, better lighting and building comfort and worker health and productivity; see in particular, Fisk (2000) and Kumar and Fisk (2002) as reported in Kats (2003).

According to Choi (2009) the benefits of green development are often not tangible; they are only evident over the longer period with lower operating costs, healthier tenants, and a positive environmental and social impact on the surrounding community. Choi recommends documenting and communicating the cost, benefits, and performance of green buildings as part of the strategy to increase adoption of green development practices. The aim of this research is an attempt to aid this communication process.

The next section will briefly describe the research methodology and data set. The results are then discussed; focusing first on specifics about the buildings adopted for analysis and then the responses to the interviews. The final section provides a summary and conclusion.

\section{METHODOLOGY AND DATA}

While there is a limited number of sales of green buildings in Australia to enable a statistically robust quantitative study to be undertaken to estimate if there is a value premium paid for such buildings that would provide a "business case" for green development, there are a growing number of best practice examples that can be adopted as case studies for analysis. The drivers, barriers, and successes involved in the delivery of sustainable building outcomes were investigated. This involved conducting field research: inspecting best practice buildings and using participatory techniques, including interviews with key stakeholders in the commercial property sector.

Various steps were involved in identifying the most highly rated commercial buildings in Australia, as well as identifying key stakeholders involved. These steps are outlined below:

- The NABERS and Green Building Council of Australia (GBCA) databases of rated building were obtained that enabled the most highly rated buildings to be identified in three of the largest cities in Australia, as well as the owners or contacts for these buildings.

- The on-line GBCA database with associated maps enabled buildings to be identified that were centrally located to reduce travel time and expense. 
- Garry Baverstock, an early architect in solar design, and responsible for setting up the Solar Energy Information Centre in Perth, as well as winning numerous awards for his environmentally sustainable developments helped to identify the key architects around Australia involved in environmentally sustainable designing.

- CEO of the GBCA, Romily Madew, suggested buildings not yet listed on the GBCA database to include in the database.

Stakeholders identified included: architects; developers; facility managers; project managers; property managers; sustainability managers, and tenants. They were contacted by email and phone to identify their willingness to participate in this research. Those willing to be involved helped the final list of properties to be confirmed.

A total of twenty-two buildings were selected for the case studies: five in Adelaide; eleven in Melbourne and six in Sydney (see Appendix 1). Twenty-three interviews were held with a range of stakeholders, some of whom were also tenants within the identified buildings. Table 1 shows that the highest proportion of respondents (48\%) was architects, with tenants (30\%) and project managers/sustainability managers (26\%) being the next largest group. This indicates that the views of a wide range of stakeholders/property professionals were obtained.

\section{Table 1: Stakeholders interviewed}

\begin{tabular}{llllllll}
\hline City & $\begin{array}{l}\text { No. } \\
\text { buildings }\end{array}$ & $\begin{array}{l}\text { Facilities } \\
\text { manager }\end{array}$ & Tenant & Architect & $\begin{array}{l}\text { Project mgr/ } \\
\text { sustainability } \\
\text { manager }\end{array}$ & $\begin{array}{l}\text { Property } \\
\text { manager }\end{array}$ & $\begin{array}{l}\text { Developer/ } \\
\text { owner }\end{array}$ \\
\hline Adelaide & 5 & 1 & 1 & 3 & & 1 & 1 \\
Melbourne & 11 & & 5 & 6 & 3 & 1 & 1 \\
Sydney & 6 & 1 & 1 & 2 & 3 & & \\
\hline TOTAL & $\mathbf{2 2}$ & $\mathbf{2}$ & $\mathbf{7}$ & $\mathbf{1 1}$ & $\mathbf{6}$ & $\mathbf{2}$ & $\mathbf{2}$ \\
\hline
\end{tabular}

Building inspections and interviews were carried out between 24th August and 1st September 2009. A survey instrument was employed to guide the interview questions. This was based on an on-line survey developed as part of parallel research to survey building professionals. The latter survey is part of on-going research to investigate the drivers and barriers for sustainable development. The interviews were combined with a building tour and generally lasted between one to one and a half hours.

The buildings inspected had either a GBCA or NABERS rating or had won significant sustainability awards. GBCA ratings are either "Office Design" (OB), or "As Built" $(\mathrm{AB})$ and range from 4 to 6 stars Green Star. 4 stars signify 'Best Practice' in environmentally sustainable design and/or construction and 6 stars signify "World Leadership”. "Office Design” evaluates the environmental potential of the design of 
commercial offices (base buildings), for both new and refurbished projects whereas "As Built" assesses the delivery of the same design criteria as in "Office Design", but at construction completion. Thus, projects can only be assessed for "As Built" after the building has been completed and has been operational for at least 12 months, as it requires collection of energy and water use data, amongst other information, over that period of time. Of the 184 certified Green Star projects, only seventeen of them are "As Built". There are reasons for this low number that will be discussed in the next section.

Another GBCA rating is for the interior fit-out of an office (FO). The Green Star Office Interiors rating tool is designed for building owners, tenants and interior designers to assess the environmental impact of an interior fit-out. A green fit-out will include issues such as access to natural light, waste management, energy conservation, low emission paints and timber from sustainable forests (GBCA, 2009).

NABERS measures an existing building's environmental performance during operation (NABERS 2008). NABERS rates a building on the basis of its measured operational impacts and may include energy, water, waste and indoor environment. It benchmarks a building's greenhouse impact on a scale of one to five: one star being the most polluting and five stars the least.

Three of the case study buildings had neither a GBCA nor a NABERS rating. This was because two of them are educational facilities (one high school and one technical college), for which no educational tool yet exists (still in the pilot stage). The only office building in the sample that did not have a rating was an historic building refurbished prior to the establishment of the GBCA in 2003. However, each of these buildings has won various awards for their sustainable features. For example, the office building has won the following awards:

- The Premier's Sustainability Award 2003

- Banksia Awards 2003: Winner Category 10: Leadership in Sustainable Buildings

- Australian Property Institute, 2003 Excellence in Property Awards: Winner Colonial First State Environmental Development Award

- Planning Institute Australia - Victorian Division - 2003 Awards for Planning Excellence: Winner Ecologically Sustainable Development (Built) Award.

Table 2 shows the type of ratings of the building sample. As we were attempting to survey best practice, it is not surprising that ten (47\%) of the GBCA rated sample buildings had the highest green star rating possible "World Leadership" (7OD, 1AB, 1Pilot, $1 \mathrm{FO}$ ); eight (42\%) represented "Australian Excellence" with 5 star ratings (4OD, 3AB, 1FO), and only one was rated as "Best Practice" with 4 stars. Only eight of the sample buildings had also undertaken a NABERS rating, with five of these (62.5\% of NABERS rated buildings) achieving the highest level of rating at 5 stars. 
All 6 star Green Star rated buildings in Adelaide, Melbourne, and Sydney were included in the sample.

Table 2: Green star \& NABERS ratings

\begin{tabular}{|c|c|c|c|c|c|c|c|c|c|c|c|}
\hline City & $4 * \mathrm{AB}$ & $5 * \mathrm{AB}$ & $6 * \mathrm{AB}$ & $5 * \mathrm{OD}$ & $6 * \mathrm{OD}$ & $5 * \mathrm{FO}$ & $6 * \mathrm{FO}$ & 6*Pilot & $4 * \mathrm{~N}$ & $4.5^{*} \mathrm{~N}$ & $5 * \mathrm{~N}$ \\
\hline Adelaide & 1 & 2 & & 1 & 1 & & & & & 1 & 2 \\
\hline Melbourne & & & 1 & 2 & 2 & 1 & 1 & 1 & 1 & 1 & 2 \\
\hline Sydney & & 1 & & 1 & 4 & & & & & & 1 \\
\hline TOTAL & 1 & 3 & 1 & 4 & 7 & 1 & 1 & 1 & 1 & 2 & 5 \\
\hline
\end{tabular}

Four existing buildings that have received a Green Star Office Design rating were included in the sample. Two have achieved 6 star Green Star status; 39 Hunter St, Sydney and 40 Albert Rd, Melbourne and two achieved 5 Star Green Star: 88 George St, Sydney and 530 Collins St, Melbourne. Two of these buildings are heritage listed and two are 1980's structures. Two other heritage buildings in the sample were not listed: one has submitted an application for a 5 Star Office Interiors rating and the other, mentioned above was refurbished before the GBCA was established, but won prestigious awards in recognition of the sustainable features within the building. The remaining sixteen buildings in the sample were completed within the last five years.

\section{RESULTS}

\section{Environmentally sustainable building features}

In the sample of buildings inspected, a number of sustainable features were identified. Not every building had all features, but from the interviews, it became apparent that the features selected for inclusion were motivated heavily by the GBCA rating tools and desire to achieve a certain GBCA "Design” rating outcome. However, while there is a perceived need to obtain a Green Star rating in order to market a building to potential investors and/or tenants, the motivation to go the next step to obtain the "As Built” rating after construction was far less. Having successfully marketed the building, interviewees generally felt that the time, effort and cost in obtaining an "As Built" rating was not worth it. A NABERS rating, which also measures how the building is performing, was considered more important than the Green Star "As Built" rating when weighed against the time and cost factors involved in achieving these.

Not surprisingly, cost was a major factor for not including certain features in the buildings. According to the Green Building Council of Australia's matrix of cost versus sustainability (GBCA, 2008b), the following items are considered to be the lowest cost and highest sustainability benefit:

- Building user training program

- Automatic HVAC switch off

- Passive solar orientation

- Fire test water retention 
- Reduction in photocopiers/printers due to dedicated rooms

- T5 fluorescent lighting

- Xeriscape landscaping

- Zero ODP building insulation

- Energy use targets and monitoring.

Where possible, many of the buildings in the sample included all of the above features. Those features not achievable were due to site constraints, surrounding buildings or existing structure constraints. Other features included consistently in the sample were: zero or low ODP refrigerants; internal plants (GBCA suggest one plant/person); low VOC paints, stains, adhesives, sealants, carpets; water efficient fixtures and fittings; high frequency ballasts; efficient lighting design and zoning; PVC minimization in materials, and bicycle storage, change rooms, and showers. The following table shows how many of the sample office buildings ( $n=19)$ included the described features:

\section{Table 3: Sustainable features}

\begin{tabular}{lllllll}
\hline Atrium & $\begin{array}{l}\text { Campus } \\
\text { style/ } \\
\text { open plan }\end{array}$ & $\begin{array}{l}\text { Heating \& } \\
\text { cooling }\end{array}$ & $\begin{array}{l}\text { Use of } \\
\text { renewabl } \\
\text { e energy }\end{array}$ & $\begin{array}{l}\text { Bike racks, } \\
\text { showers, } \\
\text { lockers }\end{array}$ & Grey-water & $\begin{array}{l}\text { Co- } \\
\text { generation } \\
\text { plant }\end{array}$ \\
\hline 10 & $17(71 \%)$ & $\begin{array}{l}\text { Variable air } \\
\text { volume systems: } 9 \\
(47 \%)\end{array}$ & $10(53 \%)$ & $19(100 \%)$ & $8(42 \%)$ & $5(26 \%)$ \\
& & & & & \\
& & $\begin{array}{l}\text { chilled beams } 8 \\
(42 \%)\end{array}$ & & & \\
\hline
\end{tabular}

Heating and cooling systems varied with variable air volume (VAV) systems making up 47\% (9), chilled beams 42\% (8), with only one office building (and the Melbourne Convention and Exhibition Centre) using an underfloor air displacement system. Other systems used in the remaining $10.5 \%$ (2) of the sample buildings included: reverse cycle split system and a gas driven variable refrigerant volume (VRV) system. ${ }^{5}$ Most of the buildings also had the ability to provide natural ventilation through operable windows.

The renewable energy sources adopted (excluding purchasing Green Energy), the most predominant application was solar panels $(26 \%, n=5)$ for heating hot water within the building; 16\% (3) had a harbour heat rejection system (saves water and replaces the need for cooling towers), and $16 \%$ had photo-voltaic solar energy arrays. Only one of the buildings made use of wind energy.

\footnotetext{
${ }^{5}$. The volume or flow rate of refrigerant is accurately matched to the required heating or cooling loads thereby saving energy and providing more accurate control.(Source:

http://www.comfort.uk.com/faq.htm\#vrv, accessed 30 September 2009)
} 
The most expensive systems to include in buildings are photo-voltaic arrays, wind turbines, gas co-generation plants, grey water treatment plants, chilled beam cooling systems, air displacement ventilation and low E double glazing. It was not surprising that the building that had the most extensive use of these features (Council House 2 (CH2), Melbourne) was funded by the government at a cost premium of $22.1 \%$ (\$11.3million AU). However, it must be noted that this cost was offset by increases in the productivity of staff, which together with the savings in energy from the ESD features reduced the payback time considerably (5-7 years) (see section 2.2.3 below). The SA Water building in Adelaide also included an extensive use of sustainable features at a cost premium of $10 \%$. Many of the newer buildings are now trying to achieve a sustainable outcome at low or no cost premium. This was a direct goal of "The Gauge" building in Melbourne. Lend Lease architect, Darren Kindrachuk, describes The Gauge as "representing an environment solution at a highly competitive construction cost, delivered on the conventional cost of a commercial building." 6

Annual savings and reductions in greenhouse gas emissions varied widely between buildings, depending on the ESD features within them. For example, 60 Leicester Street Melbourne that was built in 1870 and refurbished in 2002 consumed only a third of the energy of a typical commercial building. Workplace6 in Sydney that was completed in 2008 and has a black water treatment plant, a gas powered co-generation plant and a harbour heat rejection system reduced greenhouse gas emissions by $70 \%$, saved $90 \%$ on water consumed and $45 \%$ on energy. The harbour heat rejection system saved 4.8million litres of water p.a.

\section{Productivity studies}

Six (27\%) of the sample buildings' tenants have commissioned Building User Surveys/Productivity Studies to determine the impact of relocating to their new space. Such studies are an increasingly important part of ensuring the ESD principles actually work and also provide the business case for going green. For example, a postoccupancy study by Paevere and Brown (2008) of CH2 found that productivity increased $10.9 \%$ by moving from their former building $\mathrm{CH} 1$, to $\mathrm{CH} 2$. Their study included physical indoor environmental quality (IEQ) measures, as well as evaluation of occupant health, wellbeing and productivity based on occupant questionnaires, spot health symptoms questionnaires, focus group interviews, sick leave (absenteeism) and staff turnover data. For the occupant surveys, they received responses from more than 260 employees in $\mathrm{CH} 1$ and $\mathrm{CH} 2$. The $10.9 \%$ productivity increase translates to an annual cost saving of \$2.4million (AU). According to Professor Rob Adams, Project Director for $\mathrm{CH} 2$, this saving, together with savings in energy of $\$ 370,000$ from the ESD features of the building, will reduce the payback time to between just five and seven years. ${ }^{7}$

\footnotetext{
6. Interview with Darren Kindrachuk, Lend Lease, Sydney Tuesday 1st September 2009.

${ }^{7}$. Interview with Prof. Rob Adams, Project Director CH2, Melbourne City Council, Wednesday 26th August 2009.
} 
The results of this productivity study were similar to those from other productivity studies from the sample buildings. Generally, employees were highly satisfied with their new premises, the facilities, and the fit-out. However, the most common areas for concern were thermal comfort, which was either perceived as too cold and/or that there was too much draft (50 Lonsdale St), or conversely that there was not enough airflow (CH2). Another area for concern that was the space was too noisy (CH2, CCT1 and 50 Lonsdale), or did not have enough natural light (CH2 and Szencorp). The noise issues are not surprising, as many of these employees have moved from individual offices to an open plan environment. The response to results from the building user surveys by the building owner/manger has been to introduce more tasklighting, and tenant education programs to teach about the building controls, such as heating, cooling, lighting and how tenants can influence these. Szencorp's response to this aspect of the survey results is to investigate the use of The Green Training Company's online educational program to enhance tenants' understanding of environmental issues.

\section{Interview results}

Each building is a unique case study, but for the sake of brevity and confidentiality the results from the interviews will be summarised. As interviewees comprised a range of stakeholders: architects; facilities managers; tenants; property managers; developer/owners, etc not all questions were relevant to each type of interviewee. As such, response rates to individual questions are not provided below.

The majority of the sample buildings were high-rise offices (82\%), one was a convention and exhibition centre, two were educational campuses, and one was a single floor office fit-out. Of the office buildings, Net lettable areas ranged from $1,200 \mathrm{~m}^{2}$ (Szencorp Building, Melbourne) to $65,775 \mathrm{~m}^{2}$ (Stock Exchange building, Melbourne), with an average size of $19,253 \mathrm{~m}^{2}$. The buildings are from 2 to 38 storeys high, with an average of 10 storeys. Of the buildings where the Property Council of Australia building grade was known (9 in total), eight of these had a PCA A-grade, and one was a PCA premium-grade building. Bicycle racks, showers and lockers were provided in all office buildings with racks ranging from accommodating 12 bikes (88 George St, Sydney) up to 260 bikes (Macquarie Bank building, Sydney).

\section{The main drivers for ESD?}

Generally, the demand for ESD was driven either by the tenant $(36 \%, n=8)$, owner/investor $(36 \%, n=8)$, or the Government $(27 \%, n=6)$. Many respondents wanted to show leadership in sustainability, especially where the company has a strong environmental focus or sustainability policy. For example, Melbourne City Council has sustainability as a core policy: Melbourne 2020 program targets zero net emissions and reducing the city's water consumption by $12 \%$. The Council premises were to reinforce the Melbourne 2020 plan and to be a demonstration project. Another government example is the Sydney Harbour Foreshore Authority with its vision of 
sustainability, social responsibility and economic viability of The Darling Harbour, The Rocks and Barangaroo precincts and an ambitious target to be carbon neutral by 2010. Integral to this sustainability strategy is the pledge to the Green Star Business Partnership to adopt a minimum Green Star rating for all new buildings and major refurbishments.

In addition to government, private companies are also showing leadership in ESD. Szencorp wanted to set the benchmark of sustainable buildings in Australia and demonstrate the commercial viability of sustainable development. Further, they wanted the building to act as a test bed for innovative technologies to be demonstrated and commercialised. Building owners/developers such as GPT (General Property Trust), Lend Lease, Brookfield Multiplex, and Investa each have a strong sustainability agenda. For example, GPT signed a voluntary Sustainability Covenant, a statutory agreement under section 49AA of the Environment Protection Act 1970 in February 2008 with EPA Victoria (GPT, 2008). The parties agree to work together to reduce the ecological impact of GPT's Australian assets and operations, amongst other things.

Other interviewees see ESD as leverage to attract young Gen-Y staff that value sustainable features and want to work in environmentally friendly buildings. Investor interviewees also want to future proof their property asset, as there is a perception in the market that if the building is not green they will not be able to lease or sell it in the future.

\section{The most successful actions and ESD features}

Three of the interviewees felt that the success of the development was in the design process, selecting a dedicated team and getting the whole team involved early in the process, including the contractors. They felt this "holistic approach" was critical to getting commitment from the outset and allowed the team to find the most innovative solutions to achieve the best outcome. For example, for CH2 in Melbourne, the design approach taken by the project director, Professor Rob Adams, was to bring over from Zimbabwe, architect Mick Pearce, known for his innovative skills in designing green buildings. Following a tender process, the team was then invited and paid an additional fee to debate, brain storm, create, and design the best outcome. This "integrated approach" approach is also identified by Choi (2009) as a key component for successful green building projects.

In terms of achieving a cost effective outcome, a number of interviewees stressed the importance of a truly green philosophy: "If you don't need it, don't have it". For example, savings were made by not painting columns, not using elaborate or expensive common area finishes and flooring, etc. Further, only the most cost effective green measures were adopted, such as solar passive design. This costconsciousness was also given as a reason not to include black water treatment plants, 
photovoltaic arrays or other expensive features. When this philosophy was followed, the additional cost of building a Green Star rated building was either zero or only 1$2 \%$ premium, over a comparable non-green office building. Other interviewees that incurred much higher cost premiums were commonly owner-occupiers who were able to gain the benefits of increased staff productivity and savings in energy and water costs and were also using their building as a demonstration project (CH2) or as a test bed for innovative technologies to be demonstrated and commercialized (Szencorp).

Of the ESD features that were considered most successful, chilled beam technology was mentioned by a number of interviewees. Not only did the chilled beam system need less ceiling height, so additional floors were able to be added from the ceiling height saved (more NLA and thus, more rent and more building value), but they do not need balancing as they self regulate. Space is saved as there are no ducts needed to pump air -instead the convection currents created (hot air rises, cold air falls) circulate the air (swirl vents help aid this). The chilled beam system also uses less energy than a regular air conditioning system. However, one interviewee that has experience with variable air volume HVAC systems considered this type to be very energy efficient as well (and less expensive to install). ${ }^{8}$

The skill and quality of the facility manager, and the sophistication of the BMS to closely monitor the building, were seen as critical to the success of how well the building performed and whether it could achieve the desired NABERS rating. ${ }^{9}$

Reducing heat at the façade through the use Low E double glazing (high performance insulated glazing) was another mentioned successful ESD feature, though it was noted to be very expensive (the payback time at today's energy costs is so long that it is not justified on purely economic grounds). The Low E glass provides $80 \%$ more light so there is less need for artificial lighting.

\section{What did not work and the lessons learned}

Temperature was mentioned as an issue in a number of the buildings, with the most common tenant complaint being that it was too cold, especially where it is regulated by zone, automatically. The swirl diffusers used to help circulate the cool air from the chilled beam systems was reported to create a draft of cold air, a complaint received

\footnotetext{
${ }^{8}$. An independent reviewer for this paper responded that "VAV systems when in a fit-out situation cannot provide the ability to provide outside air rates consistently, due to the variable throttling (an issue the GBCA do not properly evaluate). VAV systems that are energy efficient in obtaining high ratings usually come at the expense of IEG and amenity.” (Email correspondence from Matthew Salisbury, WSP Lincolne Scott, 2 December 2009).

9 . While the commissioning and tuning of Central City Tower was considered long enough, the capability of the industry in actually tuning a building to perform better was uncovered. "They (the facility managers) really had no idea or interest.” (Email correspondence from Matthew Salisbury, WSP Lincolne Scott, 2 December 2009).
} 
by occupiers. ${ }^{10}$ Facilities managers can change the set points if need be, but finding a balance to satisfy everyone is problematic, and the solution was considered to be more of an education process, teaching occupants the need to treat the building like "a third skin” and dress appropriately.

Many interviewees noted that these buildings are becoming too technical and complex requiring not only more regular, but finer, tuning. An average building only needs tuning annually, whereas high performance buildings require tune ups at least quarterly, adding to the operating costs of the building. Further, there was concern that the initial tuning/commissioning period after practical completion (PC) was not long enough, in some cases only a month or two. It was considered that the ideal would be for the whole design team to be involved for 12 months after PC, and at least until the NABERS rating is achieved, as the consultants are often needed to provide information for the rating submission. Further, commissioning issues can be resolved more promptly if the team is still in place.

The fit-out not matching the design of the building was a more common irritation of building managers and owners. For example, to maximize light, tenants were placing their computers and desks near windows which created glare and too much heat so they compensated by using more air conditioning than necessary or ideal for the space. Further, some tenants in their fit-out use materials that are not recyclable, have PVC content in them, or off-gas, which contradicts the ideals of the base building.

Other issues mentioned, include:

- Some of the GBCA approved materials were only available from overseas or interstate which added to the cost and time to acquire them (and increased the embodied energy of the product).

- Water efficient toilets (2/4 litre dual flush): these had too little water that did not wash away effluent (it cleared the bowl but not the pipes). These had to be replaced with less water efficient toilets (3/6 litre dual flush) to overcome this.

- Atrium: heated up excessively and created glare (despite being designed as a heat soak, and for light and natural ventilation)

- Bike credits require a bike-friendly city (with bike paths, lower traffic, less pollution)

- Connecting the co-generation plant to the electricity grid took a lot of time to negotiate with the various government departments

\footnotetext{
${ }^{10}$. An independent reviewer for this paper responded that "chilled beams are controlled such that there is never a humidity issue internally. The air is dehumidified to an acceptable level prior to entry into the building and also the beams have humidity control sensors. The swirl diffusers have no connection with the operation of the chilled beams and are independent providing very low velocity outside air at $100 \%$ above code requirements. Recent studies have demonstrated CO2 levels at 450ppm in the building almost matching external conditions at 400ppm, whereas traditional buildings are deemed to be problematic at 1000ppm.” (Email correspondence from Matthew Salisbury, WSP Lincolne Scott, 2 December 2009).
} 
- Wind turbines were too heavy - do not turn sufficiently to generate energy (however, they still aided with drawing air out of the building)

A number of respondents mentioned ESD features that enable a developer to get to a 6 star Green Star solution, such as co or tri-generation plants and grey or black water treatment plants, are cost prohibitive and better on a precinct basis, than on building by building basis.

One interviewee felt that in order to make a building as environmentally sustainable as possible, some form of regulation and monitoring of tenant behavior is essential. Some companies have implemented environmental management plans (EMP), but the approach taken for the 60L Building in Melbourne was even more proactive by incorporating compliance with the EMP as part of the legally binding lease agreement. At a minimum, empowering occupiers to take responsibility for their actions by providing real-time data on the performance of the building's energy, water and waste systems, was recommended by some interviewees.

\section{Factors that prevent the uptake of ESD?}

Many interviewees commented on cost and the current difficult financial times, as a reason fewer owners/investors are taking up ESD initiatives. From a tenant perspective, location and rent were said to be still more important to most tenants than environmental, or energy saving features. The need for tenant buy-in was considered essential: if they do not value ESD features, they will not be willing to pay for them.

The cost of, and problems with, ESD features were mentioned as issues. Photovoltaic cells, black water treatment plants and co-generation plants are considered too expensive, with the embodied energy to produce them commonly being much more than the savings gained from having them. Fly ash (a recycled component in concrete) takes longer to cure, but means that it is not as strong requiring bigger columns for structural strength, which translates into less Net Lettable Area (NLA) and less rent. Further, the additional time involved and consultants needed for Green Star certification, compounds the cost issue.

The lack of skilled facility managers was mentioned as an ongoing and mounting issue, especially with more high performance buildings coming on stream. The building mangers employed had to be trained how to run the Building Management System (BMS) and closely monitor performance and finely tune the buildings. As noted by one interviewee, an average building needs a tune up annually, high performance buildings need a tune up quarterly (or more regularly). Further, these specialized buildings commonly need more monitors, and more data recording than an average building. 
In terms of existing buildings that make up around $97 \%$ of the building stock, respondents mentioned the need for a strong business case to encourage building owners to upgrade their buildings to be more environmentally sustainable. While there continues to be a lack of rental or sales evidence to show that the market is willing to pay for ESD, then energy and water savings, and less easily quantifiable productivity studies, are the only means to measure the benefits from ESD in monetary terms. Currently, without strong evidence to show that the benefits of "going green" outweigh the costs, there is no incentive for owners to act.

Most of the interviewees acknowledged the need for government support to build, or refurbish buildings, to a green standard. Government initiatives suggested, include:

- Property tax rebate or concession,

- Changes to the Building Code of Australia - with the suggestion that this needs to incorporate Green Star for commercial buildings,

- Mandatory reporting of energy efficiency - to be phased in from 2010 for commercial buildings and 2011 for residential buildings,

- Increased cost of energy - energy prices could act as an incentive to conserve but is currently considered to be too cheap,

- Mandate the up-grading of existing buildings to a higher performance level in terms of ESD (e.g. all earthquake risk buildings in Australia have to be upgraded and strengthened to specific standards, regardless of the cost to do so) preferably, with financial incentives to do so.

With regard to the interior fit-out, interviewees mentioned the need to make it mandatory; that this match the base building, either through provisions within the GBCA rating tool or through the lease. Further, it was considered that these fit-outs be designed by a GBCA accredited professional. A few of the architect respondents thought it would be even more desirable, and beneficial, that the same design team that worked on the base building was used to design the fit-out. As the base building team was most familiar with the building, it was considered that benefits in terms of time and cost savings would accrue to the tenant client through the design team not having to learn the intricacies of the building they were designing the interior for.

\section{CONCLUSION}

This research, carried out in Australia in 2009, identifies the drivers, barriers, costs and benefits to sustainable development by investigating proven examples of best practice. Since the GBCA was established in 2003, there has been a surge of interest in, and examples of, sustainable building development. Those developers who led the way in creating some of the most innovative and sophisticated green buildings that now exist in Australia had limited local examples to learn from. Many of them had to learn from overseas examples, but where the climates and/or economies differed from 
those in Australia. These entrepreneurs took the risks, but from their experiences many have gained valuable insights of how to build green, how to avoid the mistakes of some of the earlier examples, and how to do it more cost-effectively.

This study documents some of the experiences of leaders in the field of ESD and the tenants who occupy the buildings. While the benefits of green buildings are well documented, the challenges are still unravelling. Cost is a common reason for not tackling ESD. But it is important, as mentioned in GBCA (2008), to differentiate clearly between costs that reflect overall building quality and target market and those that relate solely to green features. Fortunately, cost as a perceived barrier is slowly reducing as the needed technology, materials, knowledge and skills become more readily available and price-competitive. There is growing practical evidence in the case studies that the new generation green buildings do not need to cost more.

Some of the most successful or necessary approaches identified by interviewees are:

- $\quad$ An integrated approach to design

- $\quad$ Adopting tried and tested technologies

- Having a sophisticated BMS and skilled facilities management team to closely monitor the building to achieve peak performance

- $\quad$ Ensuring the interior fit-out matches the base building

- A building user guide and tenant education of how to use the building optimally

- $\quad$ Longer commissioning and tuning periods to ensure the building achieves desired NABERS rating.

The building features identified as most successful in achieving good sustainability outcomes, included:

- Passive solar orientation as a low-cost option to achieve good thermal attributes

- Low-E double glazing or high performance glass

- Open plan, campus style accommodation to allow maximum daylight penetration

- Chilled beam air conditioning system

- Energy use targets and monitoring

- Provision of bicycle racks, showers, and changing rooms

- Internal plants (one per employee).

While the government is providing leadership in their requirement to procure minimum Green Star rated buildings for their own occupancy, the draft National Strategy on Energy Efficiency, the Carbon Pollution Reduction Scheme, and the Mandatory Reporting legislation, there are still issues regarding uncoordinated codes, regulations and requirements between states and regulatory authorities. Some of the interviewees have experienced this first hand, with difficulties obtaining approvals for black and grey water treatment plants or not being permitted to generate energy for 
their building above a set amount of between $25-30 \%$ of peak load, despite having the technology within the building to do so, even when city power cuts still occur.

The green building movement is relatively new in Australia, but has built momentum in the last five years with 244 Certified Green Star Projects and 11 per cent of Australia's CBD commercial office buildings Green Star certified (Green Building Council of Australia, 2010). Those early adopters of environmentally sustainable development had to learn the hard way by making their own mistakes and learning what worked best in the unique Australian climatic and economic environment. This paper offers lessons from those leaders in the development of sustainable commercial buildings. Learning from their experiences can aid the development process by capitalizing on the documented successes and avoiding the mistakes made in their learning process.

\section{REFERENCES}

Australian Greenhouse Office, Department of the Environment and Water Resources (2007), National Greenhouse Gas Inventory

2005. www.greenhouse.gov.au/inventory/2005/index.html, [accessed 14 January

2008].

Australian Greenhouse Office (1999), Australian Commercial Building Sector Greenhouse Gas Emissions 1990-

2010, www.greenhouse.gov.au/buildings/publications/commercial.html, [accessed 20 December 2007].

Australian Greenhouse Office (1999), Scoping Study of Minimum Energy Performance Requirements For Incorporation Into The Building Code Of Australia, report produced by CSIRO Division of Building, Construction and Engineering $\quad$ www.greenhouse.gov.au/buildings/publications/pubs/s_study.pdf, accessed 15 January 2008.

Australian Greenhouse Office, Department of the Environment and Water Resources (2007), An Assessment of the Need to Adapt Buildings for the Unavoidable Consequences of Climate Change, report prepared by BRANZ Ltd. $\quad$ www.greenhouse.gov.au/impacts/publications/pubs/buildings-report.pdf, [accessed 15 January 2008].

Choi. C. (2009). Removing market barriers to green development: principles and action projects to promote widespread adoption of green development practices Journal of Sustainable Real Estate, 1(1), pp. 107-138.

Council of Australian Governments (2009) Action on energy efficiency and renewables, Media Statement 20 April 
2009, http://www.alp.org.au/media/0409/msccwenhpm300.php [accessed 29

September 2009].

Commonwealth Department of Environment, Water, Heritage and the Arts DEWHA, (2008), "National Framework for Energy Efficiency Mandatory Disclosure of Commercial Office Building Energy Efficiency: Consultation Regulation Document, December

8, http://www.environment.gov.au/settlements/energyefficiency/buildings/publication s/pubs/consultation-regulation.pdf, [accessed 7 September 2009].

De Wit, E. \& Webb, R. (2009), Australia: Draft Energy Efficiency Strategy, June. http://www.mondaq.com/article.asp?articleid=80986, [accessed 7 September 2009].

Department of Environment \& Heritage, Australian Building Codes Board, and the CRC for Construction Innovation, Sustainability and the Building Code of Australia, a scoping study edited by Ashe, B. and prepared by Newton, P. et al. 2003 www.construction-innovation.info/images/pdfs/Final_Report_2001-013-B01.pdf, [accessed 31 January 2008].

Dixon, T., Keeping, M. and Roberts. C. (2008), Facing the Future: Energy Performance Certificates and commercial property, a paper presented at the Pacific Rim Real Estate Society Conference, 21- $23^{\text {rd }}$ January, Kuala Lumpur, Malaysia.

Eichholtz, P. Kok, N. and Quigley, J.M. (2008),"Doing Well by Doing Good? Green Office Buildings". Berkeley Program on Housing and Urban Policy. Working Papers: Paper W08-001. April

1. http://repositories.cdlib.org/iber/bphup/working_papers/W08-001, [accessed 7 September 2009].

Energy Efficiency Working Group (2004), National Framework for Energy Efficiency: Stakeholder Consultation Report, State and Commonwealth Governments of Australia, Canberra, www.nfee.gov.au/about_nfee.jsp?xcid=64, [accessed 30 January 2008].

Fisk, W.J. (2000), "Health and Productivity Gains from Better Indoor Environments and Their Relationship with Building Energy Efficiency," Annual Review of Energy and Environment, 25:1, 537-

566. http://www.rand.org/scitech/stpi/Evision/Supplement/fisk.pdf [accessed 9 October 2009].

Fuerst, F., McAllister, P. (2009). An investigation of the effects of eco-labeling on office occupancy rates. Journal of Sustainable Real Estate, 1(1), pp. 49-64. 
GPT (2008), Sustainability

Covenant, http://epanote2.epa.vic.gov.au/EPA/Publications.nsf/d85500a0d7f5f07b4a2

565d1002268f3/073454363d2ed25eca257392001cdbaa/\$FILE/1194.pdf, [accessed 30

September 2009].

Green Building Council Australia (2007). Australia's buildings can play a major role in the fight against climate change

,. www.gbcaus.org/gbca.asp?sectionid=5\&docid=1413, [accessed 16 January 2008].

Green Building Council Australia (2008a), Green Star: An Environmental Rating System for Buildings, www.gbcaus.org/gbca.asp?sectionid=12\&docid=1434, [accessed 30 January 2008].

Green Building Council of Australia (2008b), "The Dollars and Sense of Green Buildings 2008”, http://www.gbca.org.au/docs/dollars-sense08 [accessed 23 May 2009].

Green Building Council Australia (2009), “Green Star - Office Interiors v1.1” http://www.gbca.org.au/green-star/rating-tools/green-star-office-interiors-v11/1530.htm [accessed 29 September 2009].

Green Building Council Australia (2010), “Green Star Project Directory” http://www.gbca.org.au/greenstar-projects/ [accessed 12 June 2010].

Jones Lang LaSalle (2009), The Green Phoenix: Perspectives on Sustainability, April. http://www.nzgbc.org.nz/documents/greenbuildingreading/2009/GreenPhoenix 2009.pdf [accessed 14 August 2009].

Kats, G. H. (2003) The Costs and Financial Benefits of Green Buildings, California: Sustainable Building Task Force. 2003.http://www.cap-

e.com/ewebeditpro/items/O59F3259.pdf [accessed 14 September 2009].

Kumar, S. and Fisk, W.J. (2002), “The Role of Emerging Energy Efficient Technology in Promoting Workplace Productivity and Health: Final Report,” LBNL, February 13, pp. 20-21. Available at: http://www-library.lbl.gov/docs/LBNL/497/06/PDF/LBNL49706.pdf [accessed 9 October 2009].

Miller, N., Spivey, J. and Florance, A. (2008), Does Green Pay Off, Journal of Sustainable Real Estate, July 8. http://www.costar.com/josre/pdfs/CoStar-JOSREGreen-Study.pdf [Accessed 7 September 209].

Myers, G., Reed, R., \& Robinson, J. (2008), Investor Perception of the Business Case for Sustainable Office Buildings: evidence from New Zealand, paper presented at the 
Pacific Rim Real Estate Society Conference, 21- $23^{\text {rd }}$ January. Kuala Lumpur, Malaysia.

Muldavin, S. (2008), Quantifying “Green" Value: Assessing the Applicability of the CoStar Studies,

June. www.greenbuildingfc.com/Home/ViewResearchDoc.aspx?id=34 [accessed 6

March 2010].

Newell, G. (2008), The Strategic Significance of Environmental Sustainability by Australian-listed Property Trusts, Journal of Property Investment \& Finance, 26: 6, pp. $522-540$.

Newell, G. (2009), "The significance of sustainability best practice in retail property", Journal of Retail \& Leisure Property 8:4, pp. 259-271.

NABERS (2008). “About NABERS for offices” http://www.nabers.com.au/page.aspx?cid=533\&site=2, [accessed 29 September 2009].

Paevere,P. \& Brown, S. (2008), “Indoor Environment Quality and Occupant Productivity in the CH2 Building: Post-Occupancy Summary” March. CSIRO, Report No. USP2007/23.

Pivo, G. and McNamara, P. (2005), Responsible Property Investing. International Real Estate Review, 8: 128-143.

\section{ACKNOWLEDGEMENT}

This study is part of a larger study supported under Australian Research Council's Discovery Projects funding scheme (project DP0985410). 
Appendix 1: Buildings

\begin{tabular}{|c|c|c|c|}
\hline Name & $\begin{array}{l}\text { GBCA } \\
\text { Rating }\end{array}$ & NABERS & Contact \\
\hline \multicolumn{4}{|c|}{ ADELAIDE } \\
\hline $\begin{array}{l}\text { City Central } \\
\text { Tower } 1\end{array}$ & $5 \mathrm{AB}$ & 5 & $\begin{array}{l}\text { Woods Bagot - Architect, JLL - } \\
\text { Property Manager }\end{array}$ \\
\hline $\begin{array}{l}\text { City central } \\
\text { Tower } 2\end{array}$ & 5OD & & Aspen - Developer \\
\hline VS1 (SA Water) & $6 \mathrm{OD}$ & 5 & Hassell - Architects \\
\hline Santos HQ & $5 \mathrm{AB}$ & 5 & Hassell - Architect \\
\hline Admiral House & $4 \mathrm{AB}$ & 4.5 & CBRE - Facility manager \\
\hline \multicolumn{4}{|c|}{ MELBOURNE } \\
\hline $\begin{array}{l}\text { Australian } \\
\text { Technical College }\end{array}$ & & & Spowers, Architect \\
\hline Williamstown HS & & & Spowers, Architect \\
\hline $\begin{array}{l}\text { 60L Green Blg, } \\
60 \text { Leicester St } \\
(1870)\end{array}$ & & & Spowers, Architect \\
\hline $\begin{array}{l}\text { CH2 Melbourne } \\
\text { City Council }\end{array}$ & $6 \mathrm{OD}$ & & $\begin{array}{l}\text { Prof. Rob Adams, Project director, } \\
\text { Mick Pearce, Architect }\end{array}$ \\
\hline $\begin{array}{l}\text { Stock Exchange } \\
\text { (1989) }\end{array}$ & 5OD & 4 & JLL - Property Manager \\
\hline $\begin{array}{l}\text { Sustainability } \\
\text { Victoria }\end{array}$ & AIM: $6 \mathrm{FO}$ & 5 & $\begin{array}{l}\text { Sustainability Victoria, sustainability } \\
\text { manager }\end{array}$ \\
\hline $\begin{array}{l}\text { Hassell Studio } \\
(1880)\end{array}$ & $4 \mathrm{FO}$ & 5 & Hassell - Architect \\
\hline $\begin{array}{l}\text { Melbourne } \\
\text { Exhibition Centre }\end{array}$ & 6pilot(AB) & & Woods Bagot - Architect \\
\hline $\begin{array}{l}\text { Szencorp } \\
\text { Building (1987) }\end{array}$ & $6 \mathrm{OD}$ & 5 & Szencorp - Sustainability manager \\
\hline $\begin{array}{l}\text { The Gauge } \\
\text { Docklands }\end{array}$ & $6 \mathrm{AB}$ & & Lend Lease - Architect \\
\hline NAB Docklands & 5OD & 4.5 & NAB - Head environment \& \\
\hline
\end{tabular}




\begin{tabular}{|l|r|l|l|}
\hline & & \multicolumn{3}{|c|}{ SYDNEY } \\
\hline \multicolumn{3}{|c|}{} & \multicolumn{3}{|c|}{} & $\begin{array}{l}\text { Sydney Harbour Foreshore } \\
\text { Authority - Project manager }\end{array}$ \\
\hline $\begin{array}{l}\text { 88 George Street, } \\
\text { The Rocks } \\
(1886)\end{array}$ & 6OD & Aim: 5 & JLL - Facilities manager \\
\hline $\begin{array}{l}\text { Workplace 6, } \\
\text { Darling Harbour }\end{array}$ & 6OD & & Jackson Teece - Architect \\
\hline $\begin{array}{l}\text { 39 Hunter St } \\
\text { (1916) }\end{array}$ & 6OD & Aim: 5 & Investa - Project manager \\
\hline $\begin{array}{l}\text { The Ark, North } \\
\text { Sydney }\end{array}$ & 6OD & & Muliplex - Project Director \\
\hline Macquarie Bank & 5AB & 5 & Lend Lease - Architect \\
\hline The Bond & & & \\
\hline
\end{tabular}


Appendix 2: Sustainable features

\begin{tabular}{|c|c|c|c|c|c|}
\hline $\begin{array}{l}\text { Building Design } \\
\text { \& Materials }\end{array}$ & $\begin{array}{l}\text { Plumbing/ } \\
\text { Water }\end{array}$ & Heating/Cooling & $\begin{array}{l}\text { Ventilation } \\
\text { Air Quality }\end{array}$ & $\begin{array}{l}\text { Lighting } \\
\text { Daylight }\end{array}$ & $\begin{array}{c}\text { Use of } \\
\text { Renewable } \\
\text { Energy } \\
\text { Sources } \\
\end{array}$ \\
\hline $\begin{array}{l}\text { Specialized } \\
\text { glazing (e.g. } \\
\text { Low E; double } \\
\text { glazing) }\end{array}$ & $\begin{array}{l}\text { Flow } \\
\text { restrictors } \\
\text { \&/or efficient } \\
\text { fixtures/fittin } \\
\text { gs }\end{array}$ & $\begin{array}{l}\text { Specialized glazing } \\
\text { (Low E; double) }\end{array}$ & $\begin{array}{l}\text { Low VOC } \\
\text { materials }\end{array}$ & $\begin{array}{l}\text { Specialized } \\
\text { glazing (Low E; } \\
\text { double) } \\
\text { T5 lighting }\end{array}$ & $\begin{array}{l}\text { Photo- } \\
\text { voltaic } \\
\text { arrays }\end{array}$ \\
\hline Solar passive & $\begin{array}{l}\text { Waterless } \\
\text { urinals }\end{array}$ & Chilled beams & Fresh air & $\begin{array}{l}\text { Maximize natural } \\
\text { light by siting of } \\
\text { building }\end{array}$ & Solar panels \\
\hline $\begin{array}{l}\text { Large floor } \\
\text { plates/campus } \\
\text { style/open plan }\end{array}$ & $\begin{array}{l}\text { Rainwater } \\
\text { capture }\end{array}$ & $\begin{array}{l}\text { External \& Internal } \\
\text { shading blinds }\end{array}$ & $\begin{array}{l}\text { CO2 levels } \\
\text { constantly } \\
\text { monitored }\end{array}$ & $\begin{array}{l}\text { Ext \& Int shading } \\
\text { blinds (some } \\
\text { sensor controlled) }\end{array}$ & $\begin{array}{l}\text { Wind } \\
\text { turbines }\end{array}$ \\
\hline $\begin{array}{l}\text { Recycled timber; } \\
\text { or sustainability } \\
\text { harvested timber }\end{array}$ & $\begin{array}{l}\text { Leak } \\
\text { detection } \\
\text { systems }\end{array}$ & $\begin{array}{l}\text { Multi-zone tenant } \\
\text { controlled }\end{array}$ & $\begin{array}{l}\text { Opening } \\
\text { windows }\end{array}$ & $\begin{array}{l}\text { Motion light } \\
\text { sensors }\end{array}$ & $\begin{array}{l}\text { Harbor heat } \\
\text { rejection } \\
\text { system }\end{array}$ \\
\hline $\begin{array}{l}\text { Recycled } \\
\text { materials }\end{array}$ & Sensor taps & $\begin{array}{l}\text { Thermal massing } \\
\text { (e.g. limestone } \\
\text { wall) }\end{array}$ & Indoor plants & $\begin{array}{l}\text { Open plan to } \\
\text { maximize daylight } \\
\text { penetration }\end{array}$ & $\begin{array}{l}\text { Gas powered } \\
\text { co- } \\
\text { generation } \\
\text { plant }\end{array}$ \\
\hline $\begin{array}{l}\text { Reduction in use } \\
\text { of PVC piping }\end{array}$ & $\begin{array}{l}\text { Multi-cycle } \\
\text { systems for } \\
\text { cooling } \\
\text { towers }\end{array}$ & $\begin{array}{l}\text { Perimeter water } \\
\text { pipes to assist } \\
\text { cooling }\end{array}$ & & & Fuel cell \\
\hline $\begin{array}{l}\text { Low volatile } \\
\text { organic } \\
\text { compound } \\
\text { materials }\end{array}$ & $\begin{array}{l}\text { Grey-water } \\
\text { or black- } \\
\text { water } \\
\text { recycling } \\
\text { systems }\end{array}$ & $\begin{array}{l}\text { Solar chimneys } \\
\text { (heat extraction \& } \\
\text { draw fresh air in); } \\
\text { solar panels; PV } \\
\text { cells }\end{array}$ & & & \\
\hline $\begin{array}{l}\text { No PVC backing } \\
\text { on carpet tiles }\end{array}$ & & $\begin{array}{l}\text { Separate air } \\
\text { handling units for } \\
\text { each façade \& } \\
\text { interior zone }\end{array}$ & & & \\
\hline $\begin{array}{l}\text { Fit-out to match } \\
\text { building }\end{array}$ & & $\begin{array}{l}\text { Vertical planting for } \\
\text { shading }\end{array}$ & & & \\
\hline
\end{tabular}

Email contact: sandy.bond@lincoln.ac.nz 